\title{
Functional Grammar
}




\section{Publications in Language Sciences}

Publications in Language Sciences is a series of monographs in theoretical linguistics and its more formal satellite fields of scientific inquiry. It is intended to provide an opportunity for scholars working within these areas to report rapidly on research either terminated or in some definite stage of progress. Ideally, in these publications interest, inspiration and openmindness go hand in hand.

Ger J. de Haan

Wim Zonneveld

editors 


\section{Simon C.Dik}

Functional Grammar

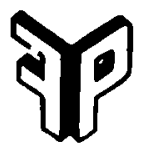

1981

FORIS PUBLICATIONS

Dordrecht - Holland/Cinnaminson - U.S.A. 
Published by:

Foris Publications Holland

P.O. Box 509

3300 AM Dordrecht, The Netherlands

Sole distributor for the U.S.A. and Canada:

Foris Publications U.S.A.

P.O. Box C-50

Cinnaminson N.J 08077

U.S.A.

First edition 1978

Second edition 1979

Third revised edition 1981

ISBN 9070176416 (Bound)

ISBN 9070176424 (Paper)

- 1981 Foris Publications - Dordrecht

No part of this book may be translated or reproduced in any form, by print, photoprint, or any other means, without written permission from the publisher.

Printed in the Netherlands by Intercontinental Graphics, H.I. Ambacht. 